\title{
Insect Antifeedant Components of Senecio fistulosus var. fistulosus-Hualtata
}

\author{
Liliana Ruiz-Vásquez ${ }^{1,2}$, , Matías Reina ${ }^{2}$, Víctor Fajardo ${ }^{3}$, Matías López ${ }^{4}$ \\ and Azucena González-Coloma ${ }^{5, *}$ (iD \\ 1 Natural Resources Research Center (CIRNA), National University of the Peruvian Amazon (UNAP), Iquitos, \\ Peru; lilyruizv@gmail.com \\ 2 Institute of Natural Products and Agrobiology (IPNA), Spanish Research Council (CSIC), 38206 Tenerife, \\ Spain; mreina@ipna.csic.es \\ 3 Faculty of Sciences, University of Magallanes (UMAG), Punta Arenas 01855, Chile; victor.fajardo@umag.cl \\ 4 University Institute of Bio-Organic Antonio González (IUBO), University of La Laguna, 38206 Tenerife, \\ Spain; mlopez@ull.es \\ 5 Institute of Agricultural Sciences (ICA), Spanish Research Council (CSIC), 28006 Madrid, Spain \\ * Correspondence: azu@ica.csic.es; Tel.: +34-917-452-500
}

Received: 22 April 2019; Accepted: 5 June 2019; Published: 15 June 2019

\begin{abstract}
From a bioactive methanolic extract of Senecio fistulosus, the antifeedant effects of the alkaloidal and non-alkaloidal fractions were tested against the insects Spodoptera littoralis, Myzus persicae and Rhopalosiphum padi, with the non-alkaloidal fraction being antifeedant. The phytochemical study of the non-alkaloidal fraction of S. fistulosus, resulted in the isolation of four compounds, two 9-oxo-furanoeremophilanes $(\mathbf{1}, \mathbf{2})$, an eremophilanolide, $1 \beta, 10 \beta$-epoxy-6-acetoxy-8 $\alpha$-hydroxy-eremofil-7(11)-en-8 $\beta, 12$-olide (3) and a maaliol derivative (4). The alkaloidal fraction yielded two known pyrrolizidine alkaloids $(5,6)$. Compounds 1,3 and 4 are new natural products. Furanoeremophilane $\mathbf{2}$ was a strong antifeedant against S. littoralis and maaliane 4 inhibited the settling of $M$. persicae.
\end{abstract}

Keywords: Senecio fistulosus; antifeedant; sesquiterpene; pyrrolizidine alkaloid; structure-activity relationships

\section{Introduction}

The genus, Senecio (Asteraceae), is distributed worldwide and contains pyrrolizidine alkaloids (PAs). PAs are toxic to mammals and feeding deterrents for insect herbivores [1]. Compounds present in the non-alkaloidal fraction of Senecio spp have been described as part of their defense [1-3]. The most frequent chemical groups found in the non-alkaloidal fraction of Senecio are eremophilane-type sesquiterpenes of the furanoeremophilane and eremophilanolide type [1]. Some of these compounds have insect antifeedant, acaricidal, fungicidal, cytotoxic, phytotoxic, antioxidant, anti-inflammatory, and antimicrobial effects [1-6] and have been proposed as being an important part of Senecio defense [1-5].

In Chile, the genus Senecio is abundant ( 210 species) [7]. There are several reports on eremophilane sesquiterpenes from Chilean Senecio species with defensive properties [1-3]. The species, Senecio fistulosus, grows from the western area of Patagonia to central Chile and it is used in folk medicine for its effects on the heart [8,9]. A previous study on the phytochemistry of $S$. fistulosus, from the central region of Chile, reported the presence of furanoeremophilanes $4 \alpha$-hydroxy-6 $\beta$-angeloxy-10 $\beta$ acetoxy-9-oxo-furanoeremophilane and $4 \alpha$-hydroxy-6 $\beta$-angeloxy-9-oxo-furanoeremophilane [10], but there are no reports on the defensive chemistry of this species. 
In this work, the authors studied the chemical defenses of S. fistulosus var. fistulosus from the Magallanic region, containing a large number of the Chilean Senecio species and subspecies distributed in the Patagonic Cordillera and the coastal areas [7].

From a bioactive methanolic extract of $S$. fistulosus, the alkaloidal and non-alkaloidal fractions were tested against the insects Spodoptera littoralis (Boisd), Myzus persicae (Sulzer) and Rhopalosiphum padi, with the non-alkaloidal being antifeedant. Two furanoeremophilanes $(\mathbf{1}, \mathbf{2})$, one eremophilanolide (3) and maaliol derivative (4) have been isolated from the non-alkaloidal fraction, with compounds 1, 3 and 4 being reported as natural products for the first time. Additionally, two pyrrolizidine alkaloids (5, 6) were isolated from the alkaloidal fraction.

\section{Results and Discussion}

Extracts of S. fistulosus (methanolic, $\mathrm{MeOH}$, non-alkaloidal and alkaloidal) were tested against the phytophagous insects Spodoptera littoralis, Myzus persicae and Rhopalosiphum padi. The $\mathrm{MeOH}$ extract showed a significant effect on M. persicae (SI $=78 \pm 4 \%$; $\mathrm{EC}_{50}=1.69 \mu \mathrm{g} / \mathrm{cm}^{2}, 0.69-4.15,95 \%$ confidence limits-CL), the non-alkaloidal extract was active on S. littoralis (FI $=76 \pm 6 \%$ ) and $M$. persicae (SI $=75 \pm 6 \% ; \mathrm{EC}_{50}=2.25 \mu \mathrm{g} / \mathrm{cm}^{2}, 1.19-4.24,95 \% \mathrm{CL}$ ). The alkaloidal extract showed moderate activity against $S$. littoralis $(\mathrm{SI}=62 \pm 6 \%$ ) and $R$. padi $(\mathrm{SI}=69 \pm 6 \%$ ), indicating that $S$. fistulosus defense chemistry is mainly due to compounds present in the non-alkaloidal fraction, as previously suggested for PA producing plants [2-4,11].

The phytochemical study of the non-alkaloidal fraction of $S$. fistulosus resulted in the isolation of four compounds, two 9-oxo-furanoeremophilanes $(\mathbf{1}, \mathbf{2})$ [10,12], an eremophilanolide, $1 \beta, 10 \beta$-epoxy-6-acetoxy- $8 \alpha$-hydroxy-eremofil-7(11)-en-8 $\beta, 12$-olide (3) and a maaliol derivative (4). The alkaloidal fraction yielded two known pyrrolizidine alkaloids $(\mathbf{5}, \mathbf{6})[13,14]$ (Figure 1).

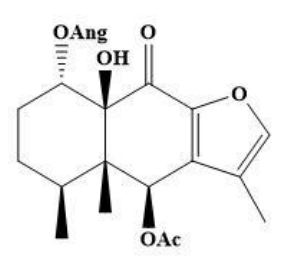

1

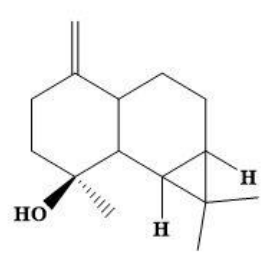

4

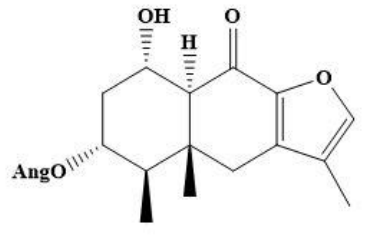

2

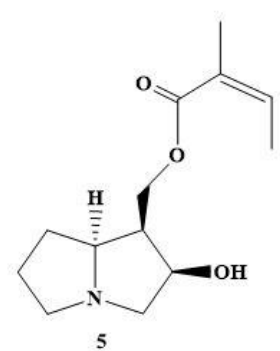

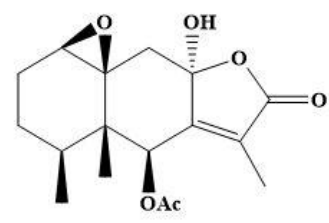

3

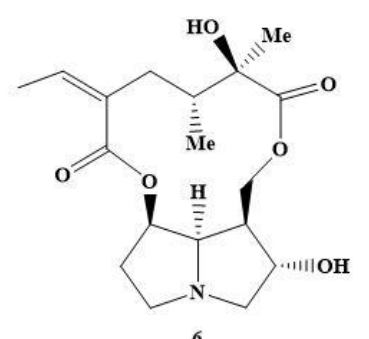

Figure 1. Chemical structures of compounds 1-6.

Compounds 1, 3 and 4 are described here for the first time as natural products. A previous study on S. fistulosus reported the presence of furanoeremophilanes $4 \alpha$-hydroxy- $6 \beta$-angeloxy-10 $\beta$ acetoxy-9-oxo-furanoeremophilane and $4 \alpha$-hydroxy- $6 \beta$-angeloxy-9-oxo-furanoeremophilane [10]. The difference in furanoeremophilane composition could be related to the different origin of the plant populations studied (Magallanes versus the central region of Chile).

The structural elucidation was carried out based on their ${ }^{1} \mathrm{H}$ and ${ }^{13} \mathrm{C}$ NMR spectra including (1D) and (2D) (COSY, HSQC, HMBC and NOESY) experiments, X-ray diffraction, as well as its physical, spectrometric (EIMS and HREIMS) and comparison with the chemical bibliography reported for similar compounds. 
Compound 1 was isolated in crystalline form. Its infrared (IR) spectrum showed absorption bands at 3452,1748, 1720 and $1679 \mathrm{~cm}^{-1}$ attributable to a hydroxyl, ester, and carbonyl groups. Its HR-EI-MS showed a molecular-ion peak at $m / z 404.1838\left(\mathrm{M}^{+}\right.$, calculated for $\left.\mathrm{C}_{22} \mathrm{H}_{28} \mathrm{O}_{7}, 404.1835\right)$ and a major fragment in the upper part of the spectrum at $345(3 \%)\left[\mathrm{M}-\mathrm{OCOCH}_{3}\right]^{+}$. The ${ }^{1} \mathrm{H}$ and ${ }^{13} \mathrm{C} \mathrm{NMR}$ spectra of compound 1 (Table 1) showed signals of an olefinic proton at $\delta(\mathrm{H}) 7.41$ (br s, $J=1.3, \mathrm{H}-\mathrm{C}(12)$ ) and one methyl group on a double bond at $\delta(\mathrm{H}) 1.91(\mathrm{~d}, J=1.1, \mathrm{Me}(13))$, indicating the presence of a furan ring with a methyl group at $\mathrm{C}(11)$. The chemical shifts of signals $\delta(\mathrm{H}) 0.98(\mathrm{~s}), 1.17(\mathrm{~d}, J=7.5)$ assigned to $\mathrm{Me}(14)$ and $\mathrm{Me}(15)$, indicated a cis-decalin system [10]. Signals at $\delta(\mathrm{H}) 3.98$ (br s) were assigned to a proton on a hydroxyl group, and signals at $\delta(\mathrm{H}) 5.92\left(\mathrm{qq}, J=1.5,7.2, \mathrm{H}-\mathrm{C}\left(3^{\prime}\right)\right), 1.88(\mathrm{dq}, J=1.6,7.4$, $\left.\mathrm{Me}\left(4^{\prime}\right)\right), 1.55$ (quint., $\left.J=1.5 \mathrm{~Hz}, \mathrm{Me}\left(5^{\prime}\right)\right) ; \delta(\mathrm{C}) 126.6\left(\mathrm{~s}, \mathrm{C}\left(2^{\prime}\right)\right), 140.5\left(\mathrm{~d}, \mathrm{C}\left(3^{\prime}\right)\right), 15.8\left(\mathrm{q}, \mathrm{C}\left(4^{\prime}\right)\right), 19.9(\mathrm{q}$, $\left.\mathrm{C}\left(5^{\prime}\right)\right)$ corresponded to an angelate group. The chemical shift at $\delta(\mathrm{H}) 7.03$ (s) was attributed to $\mathrm{H}_{\alpha}-(6)$, a geminal proton of an acetate group $\left[\delta(\mathrm{H}) 2.19\left(\mathrm{~s}, \mathrm{OCOCH}_{3}\right) ; \delta(\mathrm{C}) 20.9(\mathrm{q})\right.$ and $\left.170.9(\mathrm{~s})\right]$. The HMBC experiment showed correlations between $\mathrm{H}-\mathrm{C}(1)$ with $\mathrm{C}(3), \mathrm{C}(5), \mathrm{C}(10)$ and $\mathrm{C}\left(1^{\prime}\right)$, which allowed for the location of the angelate group at $\mathrm{C}(1)$. Correlations of the $\mathrm{OH}$ proton with $\mathrm{C}(5), \mathrm{C}(9)$ and $\mathrm{C}(10)$ confirmed the location of the hydroxyl group at $\mathrm{C}(10)$. Correlation of $\mathrm{H}_{\alpha}-\mathrm{C}(6)$ with $\mathrm{C}(4), \mathrm{C}(8), \mathrm{C}(11)$, $\mathrm{C}(14)$ and $\mathrm{OCOCH}_{3}$ located the acetate group at $\mathrm{C}(6)$ (Figure 2). The remaining correlations were in agreement with the proposed structure. The relative stereochemistry of $\mathbf{1}$ was established by a NOESY experiment (Figure 3). $\mathrm{H}_{\beta}-\mathrm{C}(1)$ gave a positive NOE effect with the $\mathrm{H}_{\beta}-\mathrm{C}(2)$ and $\mathrm{H}_{\beta}-\mathrm{C}(3)$ signals, confirming the $\alpha$-configuration of the angelate group. In the same way, $\mathrm{H}_{\alpha}-\mathrm{C}(6)$ presented a NOE effect with protons $\mathrm{H}_{\alpha}-\mathrm{C}(4)$ and $\mathrm{Me}(13)$, establishing the configuration of the acetate group as $\mathrm{C}-6 \beta$. The NOE effect of $\mathrm{H}-\mathrm{C}\left(3^{\prime}\right)$ with $\mathrm{Me}(4)^{\prime} / \mathrm{Me}\left(5^{\prime}\right)$ and the chemical shift of $\mathrm{Me}\left(5^{\prime}\right)(\delta(\mathrm{C})=20.6 \mathrm{ppm})$ suggested the Z-geometry for the double bond of the $\mathrm{H}-\mathrm{C}\left(2^{\prime}\right) / \mathrm{H}-\mathrm{C}\left(3^{\prime}\right)$ of the angelate group. The molecular structure of 1 was confirmed by X-ray diffraction (Figure 3), resolved by direct methods with SIR97, and was established as $1 \alpha$-angeloyloxy- $6 \beta$-acetoxy-10 $\beta$-hydroxy-9-oxo-furanoeremophilane.

The HR-EI-MS of compound 2, showed a molecular-ion peak at $\mathrm{m} / \mathrm{z} 346.1785\left(\mathrm{M}^{+}\right.$, calculated for $\mathrm{C}_{20} \mathrm{H}_{26} \mathrm{O}_{5}, 346.1780$ ), and its IR spectrum showed the presence of absorption bands at 3446, 1733, 1716 and $1699 \mathrm{~cm}^{-1}$ attributable to hydroxyl, ester, and carbonyl groups. The analysis of ${ }^{1} \mathrm{H}$ and ${ }^{13} \mathrm{C} \mathrm{NMR}$ spectroscopic data of 2 (Table 1) indicated the presence of a trans-decalin based on the chemical shift at $\delta(\mathrm{H}) 0.88$ (s, Me(14)), and by comparison with published data. Therefore, the structure of 2 was confirmed as $1 \alpha$-hydroxy-3 $\alpha$-angeloyloxy-10 $\alpha$ H-9-oxo-furanoeremophilane, previously isolated from Senecio smithii, [12].

Table 1. ${ }^{1} \mathrm{H}(500 \mathrm{MHz})$ and ${ }^{13} \mathrm{C}(125 \mathrm{MHz})$ NMR data of compounds 1 and 2 in $\mathrm{CDCl}_{3}$.

\begin{tabular}{|c|c|c|c|c|}
\hline \multirow[b]{2}{*}{ Position } & \multicolumn{2}{|l|}{1} & \multicolumn{2}{|l|}{2} \\
\hline & $\begin{array}{c}\delta_{H} \text { in ppm, } \\
\text { Multiplicity, } J \text { (in Hz) }\end{array}$ & $\delta_{C}$ in ppm & $\begin{array}{c}\delta_{H} \text { in ppm, } \\
\text { Multiplicity, } J(\text { in } \mathrm{Hz})\end{array}$ & $\delta_{C}$ in ppm \\
\hline $1 \beta$ & $4.84 b r \mathrm{~s}$ & $74.5 \mathrm{~d}$ & 4.25 ddd $(4.8,9.7,11.7)$ & $65.5 \mathrm{~d}$ \\
\hline $2 \alpha$ & $2.30 \mathrm{~m}$ & & $1.50 \mathrm{q}(11.8)$ & \\
\hline $2 \beta$ & $1.64 \mathrm{~m}$ & $20.7 \mathrm{t}$ & $2.47 \mathrm{~m}$ & $39.1 \mathrm{t}$ \\
\hline $3 \alpha$ & $1.40 \mathrm{~m}$ & & - & \\
\hline $3 \beta$ & $2.32 \mathrm{~m}$ & $23.9 \mathrm{t}$ & $4.90 \mathrm{dt}(4.6,11.5)$ & $71.4 \mathrm{~d}$ \\
\hline $4 \alpha$ & $1.65 \mathrm{~m}$ & $32.3 \mathrm{~d}$ & $1.84 \mathrm{~m}$ & $46.9 \mathrm{~d}$ \\
\hline 5 & - & $50.2 \mathrm{~s}$ & - & $43.9 \mathrm{~s}$ \\
\hline $6 \alpha$ & $7.03 \mathrm{~s}$ & & $2.52 \mathrm{~d}(16.6)$ & \\
\hline $6 \beta$ & - & $68.6 \mathrm{~d}$ & $2.71 \mathrm{~d}(16.6)$ & $35.9 \mathrm{t}$ \\
\hline 7 & - & $139.4 \mathrm{~s}$ & - & $138.1 \mathrm{~s}$ \\
\hline 8 & - & $145.9 \mathrm{~s}$ & - & $146.5 \mathrm{~s}$ \\
\hline 9 & - & $186.9 \mathrm{~s}$ & - & $188.7 \mathrm{~s}$ \\
\hline $10 \beta$ & - & $79.8 \mathrm{~s}$ & $2.42 \mathrm{~d}(9.8)$ & $60.6 \mathrm{~d}$ \\
\hline 11 & - & $121.8 \mathrm{~s}$ & - & $121.7 \mathrm{~s}$ \\
\hline 12 & $7.41 b r \mathrm{~s}$ & $146.9 \mathrm{~d}$ & $7.41 \mathrm{~s}$ & $145.8 \mathrm{~d}$ \\
\hline 13 & $1.91 \mathrm{~d}(1.1)$ & $8.3 \mathrm{q}$ & $1.99 \mathrm{~d}(1.0)$ & $7.8 \mathrm{q}$ \\
\hline
\end{tabular}


Table 1. Cont.

\begin{tabular}{|c|c|c|c|c|}
\hline \multirow[b]{2}{*}{ Position } & \multicolumn{2}{|l|}{1} & \multicolumn{2}{|l|}{2} \\
\hline & $\begin{array}{c}\delta_{H} \text { in ppm, } \\
\text { Multiplicity, } J(\text { in } \mathrm{Hz})\end{array}$ & $\delta_{C}$ in ppm & $\begin{array}{c}\delta_{\mathrm{H}} \text { in ppm, } \\
\text { Multiplicity, } J \text { (in Hz) }\end{array}$ & $\delta_{C}$ in ppm \\
\hline 14 & $0.98 \mathrm{~s}$ & $15.5 \mathrm{q}$ & $0.88 \mathrm{~s}$ & $14.3 \mathrm{q}$ \\
\hline 15 & $1.17 \mathrm{~d}(7.5)$ & $16.0 \mathrm{q}$ & $0.98 \mathrm{~d}(6.7)$ & $10.5 \mathrm{q}$ \\
\hline $1^{\prime}$ & - & $165.7 \mathrm{~s}$ & - & $167.6 \mathrm{~s}$ \\
\hline $2^{\prime}$ & - & $126.6 \mathrm{~s}$ & - & $128.1 \mathrm{~s}$ \\
\hline $3^{\prime}$ & $5.92 \mathrm{qq}(1.5,7.2)$ & $140.5 \mathrm{~d}$ & $6.05 \mathrm{qq}(1.4,7.2)$ & $137.8 \mathrm{~d}$ \\
\hline $4^{\prime}$ & $1.88 \mathrm{dq}(1.6,7.4)$ & $15.8 \mathrm{q}$ & $1.97 \mathrm{dq}(1.5,7.2)$ & $15.8 \mathrm{q}$ \\
\hline $5^{\prime}$ & 1.55 quint. (1.5) & $19.9 \mathrm{q}$ & 1.88 quint. (1.5) & $20.6 \mathrm{q}$ \\
\hline $\mathrm{OCOCH}_{3}$ & $2.19 \mathrm{~s}$ & $20.9 \mathrm{q}$ & $1-$ & -1 \\
\hline $\mathrm{OCOCH}_{3}$ & - & $170.9 \mathrm{~s}$ & - & - \\
\hline $\mathrm{OH}-10$ & $3.98 b r \mathrm{~s}$ & - & - & - \\
\hline
\end{tabular}

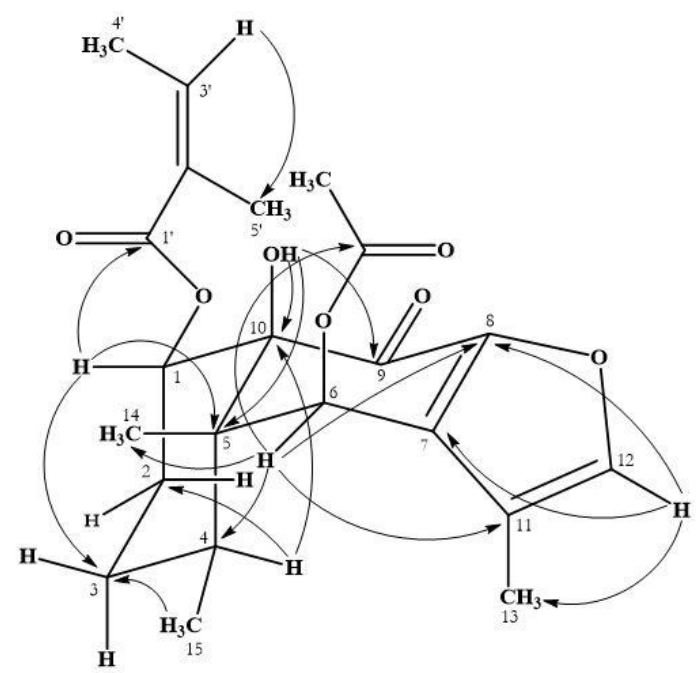

Figure 2. HMBC correlations observed for compound 1.

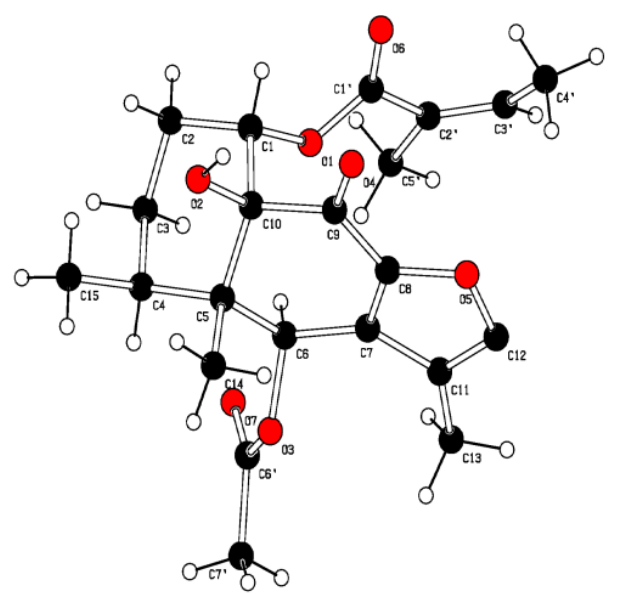

Figure 3. NOESY and ORTEP of compound 1.

The HR-EI-MS of compound 3 showed a molecular ion peak at $m / z 322.1425\left(\mathrm{M}^{+}\right.$, calculated for $\left.\mathrm{C}_{17} \mathrm{H}_{22} \mathrm{O}_{6}, 322.1416\right)$ and fragments in the upper part of the spectrum at $m / z 262(100 \%)\left[\mathrm{M}-\mathrm{CH}_{3} \mathrm{COOH}\right]^{+}$. Signals for seventeen carbon atoms were observed in its ${ }^{13} \mathrm{C}$ NMR spectrum. Their multiplicities were analyzed by a DEPT experiment which determined four methyl, three methylenes, three methines and six quaternary carbons. The ${ }^{1} \mathrm{H}$ and ${ }^{13} \mathrm{C}$ NMR spectra of 3 showed signals at $\delta(\mathrm{H}) 3.18(d, J=4.6$, $\mathrm{H}-\mathrm{C}(1)) ; \delta(\mathrm{C}) 62.7(\mathrm{~d}, \mathrm{C}-(1))$ and 60.9 (s, C-(10)), attributed to chemical shifts characteristic of an epoxide 
group at C-(1)-C-(10); signals at $\delta(\mathrm{H}) 2.20\left(\mathrm{~s}, \mathrm{OCOCH}_{3}\right) ; \delta(\mathrm{C}) 20.9\left(\mathrm{q}, \mathrm{OCOCH}_{3}\right)$ and $170.6\left(\mathrm{~s}, \mathrm{OCOCH}_{3}\right)$, corresponding to an acetate group at $\mathrm{C}(6)$, a signal for a geminal proton of an acetate group at $\delta(\mathrm{H}) 5.92$ $(\mathrm{q}, J=1.8) ; \delta(\mathrm{C}) 73.8(\mathrm{~d}, \mathrm{C}(6))$; and a signal at $\delta(\mathrm{H}) 1.87(\mathrm{~d}, J=1.8) ; \delta(\mathrm{C}) 8.2(\mathrm{q})$ corresponding to a $\mathrm{Me}(13)$. The HSQC and HMBC experiments (Table 2) confirmed the presence of an eremophilanolide skeleton and the localization of the epoxide and acetate groups, respectively. The relative stereochemistry of 3 was determined by a NOESY experiment (Figure 4). The positive NOE effect of $\mathrm{H}_{\alpha}-(6)$ with the methyl Me(13) signal was consistent with a $\beta$ configuration of the $\gamma$-lactone, which agrees with the observed homoalilic coupling constant $J_{6-13}=1.8[15,16]$ with an angle between the two bonds of about $90^{\circ}$. Therefore, an $\alpha$-configuration for the hydroxyl group at $\mathrm{C}(8)$ was determined. The observed NOE effect of $\mathrm{H}_{\alpha}-(1)$ with $\mathrm{H}_{\beta}-(9)$ confirmed the $\beta$-configuration of the epoxide. Compound 3 was identified based on its spectroscopic data as $1 \beta, 10 \beta$-epoxy- $6 \beta$-acetoxy- $8 \alpha$-methoxy-eremofil-1(10),7(11)-diene-12,8 8 -olide, previously obtained by epoxidation and subsequent acetylation of the compound $6 \beta$-hydroxy8 $\alpha$-methoxy-eremophil-1(10),7(11)-dien-12,8ß-olide, isolated from S. magellanicus [2].

Table 2. ${ }^{1} \mathrm{H}(500 \mathrm{MHz})$ and ${ }^{13} \mathrm{C}(125 \mathrm{MHz}) \mathrm{NMR}$ data of compounds 3 and 7 * in $\mathrm{CDCl}_{3}$.

\begin{tabular}{|c|c|c|c|c|}
\hline \multirow[b]{2}{*}{ Position } & \multicolumn{2}{|l|}{3} & \multicolumn{2}{|l|}{$7^{*}$} \\
\hline & $\begin{array}{c}\delta_{\mathrm{H}} \text { in ppm, } \\
\text { Multiplicity, } J(\text { in } \mathrm{Hz})\end{array}$ & $\delta_{C}$ in ppm & $\begin{array}{c}\delta_{\mathrm{H}} \text { in ppm, } \\
\text { Multiplicity, } J \text { (in Hz) }\end{array}$ & $\delta_{C}$ in ppm \\
\hline $1 \beta$ & $3.18 \mathrm{~d}(4.6)$ & $62.7 \mathrm{~d}$ & $3.14 \mathrm{~d}(4.3)$ & $63.0 \mathrm{~d}$ \\
\hline $2 \alpha$ & $1.96 \mathrm{dd}(6.8,10.8)$ & & $2.04 \mathrm{~m}$ & \\
\hline $2 \beta$ & $2.04 \mathrm{dd}(5.9,10.5)$ & $20.3 \mathrm{t}$ & $2.21 \mathrm{~m}$ & $21.0 \mathrm{t}$ \\
\hline $3 \alpha$ & $1.36 \mathrm{dc}(3.5,9.4)$ & & $1.38 \mathrm{~m}$ & \\
\hline $3 \beta$ & $1.63 \mathrm{~m}$ & $23.9 \mathrm{t}$ & $1.61 \mathrm{~m}$ & $24.2 \mathrm{t}$ \\
\hline $4 \alpha$ & $1.62 \mathrm{~m}$ & $32.5 \mathrm{~d}$ & $1.62 \mathrm{~m}$ & $33.0 \mathrm{~d}$ \\
\hline 5 & - & $43.4 \mathrm{~s}$ & - & $43.5 \mathrm{~s}$ \\
\hline $6 \alpha$ & 5.92 c (1.8) & $73.8 \mathrm{~d}$ & $5.69 \mathrm{t}(1.7)$ & $74.3 \mathrm{~d}$ \\
\hline 7 & - & $155.0 \mathrm{~s}$ & - & $153.9 \mathrm{~s}$ \\
\hline 8 & - & $101.3 \mathrm{~s}$ & - & $104.4 \mathrm{~s}$ \\
\hline $9 \alpha$ & $1.79 \mathrm{~d}(13.6)$ & & $1.80 \mathrm{~d}(13.6)$ & \\
\hline $9 \beta$ & $2.31 \mathrm{~d}(13.6)$ & $43.4 \mathrm{t}$ & $2.27 \mathrm{~d}(13.6)$ & $43.6 \mathrm{t}$ \\
\hline 10 & - & $60.9 \mathrm{~s}$ & - & $61.0 \mathrm{~s}$ \\
\hline 11 & - & $124.6 \mathrm{~s}$ & - & $126.8 \mathrm{~s}$ \\
\hline 12 & - & $170.8 \mathrm{~s}$ & - & $170.9 \mathrm{~s}$ \\
\hline 13 & $1.87 \mathrm{~d}(1.8)$ & $8.2 \mathrm{q}$ & $1.92 \mathrm{~d}(1.2)$ & $8.6 \mathrm{q}$ \\
\hline 14 & $1.09 \mathrm{~s}$ & $14.5 \mathrm{q}$ & $1.09 \mathrm{~s}$ & $14.5 \mathrm{q}$ \\
\hline 15 & $1.04 \mathrm{~d}(7.2)$ & $16.1 \mathrm{q}$ & $1.03 \mathrm{~d}(7.0)$ & $16.5 \mathrm{q}$ \\
\hline OMe-8 & - & - & $3.23 \mathrm{~s}$ & $50.9 \mathrm{q}$ \\
\hline $\mathrm{OCOCH}_{3}$ & $2.20 \mathrm{~s}$ & $20.9 \mathrm{q}$ & $2.21 \mathrm{~s}$ & $21.0 \mathrm{q}$ \\
\hline $\mathrm{OCOCH}_{3}$ & - & $170.6 \mathrm{~s}$ & - & $170.3 \mathrm{~s}$ \\
\hline
\end{tabular}

* Source: Reina et al. [2].

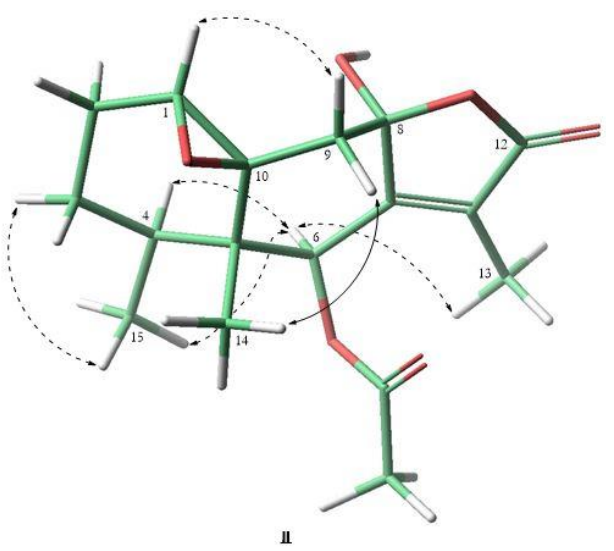

Figure 4. NOESY of compound 3. 
Compound 4 was isolated as a colorless oil. Its HR-EI-MS mass spectrum showed a molecular-ion peak at $\mathrm{m} / \mathrm{z} 220.1831\left(\mathrm{M}^{+}\right.$, calculated for $\left.\mathrm{C}_{15} \mathrm{H}_{24} \mathrm{O}, 220.1827\right)$ and fragments at $205(55 \%)\left[\mathrm{M}_{-} \mathrm{CH}_{3}\right]^{+}$and $187(19 \%)\left[\mathrm{M}^{-} \mathrm{CH}_{3}+\mathrm{H}_{2} \mathrm{O}\right]^{+}$. The presence of three tertiary methyl groups at $\delta(\mathrm{H}) 1.04(\mathrm{~s}, \mathrm{Me}(13)), 1.06$ (s, Me(12)) and 1.28 (s, Me(15)) were observed in the ${ }^{1} \mathrm{H}$ and ${ }^{13} \mathrm{C}$ NMR spectra (Table 3). An HSQC experiment showed their correlations with carbons at $\delta(\mathrm{C}) 16.5(\mathrm{q}, \mathrm{Me}(13)), 28.8(\mathrm{q}, \mathrm{C}(12))$ ), and 26.2 (q, C(15)), and signals from two hydrogens of a cyclopropane at $\delta(\mathrm{H}) 0.47(\mathrm{dd}, J=9.6,11.4, \mathrm{H}-\mathrm{C}(6))$; $\delta(\mathrm{C}) 30.1(\mathrm{~d}, \mathrm{C}(6))$ and $0.71(\mathrm{ddd}, J=6.1,9.5,11.4, \mathrm{H}-\mathrm{C}(7)) ; \delta(\mathrm{C}) 27.7(\mathrm{~d}, \mathrm{C}(7))$ [16]. Additional signals attributable to two protons at $\delta(\mathrm{H}) 4.69\left(\mathrm{t}, J=1.6, \mathrm{H}_{\mathrm{a}}-\mathrm{C}(14)\right)$ and $4.63\left(\mathrm{q}, J=1.7 \mathrm{H}_{\mathrm{b}}-\mathrm{C}(14)\right)$; a $\delta(\mathrm{C}) 106.4$ (t) signal assigned to an exocyclic methylene and a proton signal at $\delta(\mathrm{H}) 2.20\left(\mathrm{~m}, \mathrm{H}_{\beta}-\mathrm{C}(10)\right) ; \delta(\mathrm{C}) 53.6$ $(d, C(10))$ were observed. The latter signal presented HMBC correlations at $\delta_{C} 153.6(t, C-(14)), 39.1$ $(t, C(2))$ and $54.6(d, C(5))$, suggesting the location of the exocyclic methylene at $C-1$. The remaining signals were assigned by analysis of the 1D and 2D NMR spectra and by comparing these data with similar compounds. The structure of 4 was identified as the maaliol derivative (+)-1(14)-en-maaliol [17] which has not been previously isolated as a natural product.

Table 3. ${ }^{1} \mathrm{H}(500 \mathrm{MHz}),{ }^{13} \mathrm{C}(125 \mathrm{MHz})$ and $\mathrm{HMBC}$ NMR data of compound 4 in $\mathrm{CDCl}_{3}$.

\begin{tabular}{cccc}
\hline Position & $\boldsymbol{\delta}_{\mathbf{H}}$ in ppm, Multiplicity, $\mathbf{J}$ (in Hz) & $\boldsymbol{\delta}_{\mathbf{C}}$ in ppm & HMBC \\
\hline 1 & - & $153.6 \mathrm{~s}$ & - \\
$2 \mathrm{a}$ & $2.42 \mathrm{ddd}(1.3,6.3,13.3)$ & $39.1 \mathrm{t}$ & $\mathrm{C}-1, \mathrm{C}-4, \mathrm{C}-10, \mathrm{C}-14$ \\
$2 \mathrm{~b}$ & $2.05 \mathrm{~m}$ & & \\
$3 \mathrm{a}$ & $1.77 \mathrm{~m}$ & $41.9 \mathrm{t}$ & $\mathrm{C}-2, \mathrm{C}-4$ \\
$3 \mathrm{~b}$ & $1.56 \mathrm{~d}$ & $81.1 \mathrm{~s}$ & - \\
4 & - & $54.6 \mathrm{~d}$ & $\mathrm{C}-1, \mathrm{C}-4, \mathrm{C}-6, \mathrm{C}-10, \mathrm{C}-11$ \\
$5 \alpha$ & $1.32 \mathrm{~m}$ & $30.1 \mathrm{~d}$ & $\mathrm{C}-4, \mathrm{C}-8, \mathrm{C}-11, \mathrm{C}-13$ \\
$6 \beta$ & $0.47 \mathrm{dd}(9.6,11.4)$ & $27.7 \mathrm{~d}$ & $\mathrm{C}-5, \mathrm{C}-11, \mathrm{C}-13$ \\
$7 \beta$ & $1.98 \mathrm{~m}$ & & - \\
$8 \mathrm{a}$ & $1.01 \mathrm{~m}$ & $24.9 \mathrm{t}$ & \\
$8 \mathrm{~b}$ & $1.90 \mathrm{~m}$ & & $\mathrm{C}-5, \mathrm{C}-10$ \\
$9 \mathrm{a}$ & $1.63 \mathrm{~m}$ & $26.9 \mathrm{t}$ & \\
$9 \mathrm{~b}$ & $2.20 \mathrm{~m}$ & $53.6 \mathrm{~d}$ & $\mathrm{C}-1, \mathrm{C}-2, \mathrm{C}-5, \mathrm{C}-6, \mathrm{C}-14$ \\
$10 \beta$ & - & $20.4 \mathrm{~s}$ & - \\
11 & $1.06 \mathrm{~s}$ & $28.8 \mathrm{q}$ & $\mathrm{C}-7, \mathrm{C}-6, \mathrm{C}-11, \mathrm{C}-13$ \\
12 & $1.04 \mathrm{~s}$ & $16.5 \mathrm{q}$ & $\mathrm{C}-7, \mathrm{C}-6, \mathrm{C}-11, \mathrm{C}-12$ \\
13 & $4.69 \mathrm{t}(1.6)$ & $106.4 \mathrm{t}$ & $\mathrm{C}-2, \mathrm{C}-10$ \\
$14 \mathrm{a}$ & $4.63 \mathrm{q}(1.7)$ & $26.2 \mathrm{q}$ & $\mathrm{C}-3, \mathrm{C}-4, \mathrm{C}-5$ \\
$14 \mathrm{~b}$ & $1.28 \mathrm{~s}$ & & \\
15 & &
\end{tabular}

Two unsaturated pyrrolizidine alkaloids (PAs) were isolated from the alkaloidal fraction, 9-O-angeloylpetasinecine (hectorine 5), and rosmarinine (6). These alkaloids were identified by comparison of their spectral data $\left({ }^{1} \mathrm{H}\right.$ a ${ }^{13} \mathrm{C}$ NMR and EIMS) with previous reports $[13,14]$.

The antifeedant effects of compounds $\mathbf{1}, \mathbf{2}$ and $\mathbf{4}$ are shown in Table 4. Furanoeremophilane $\mathbf{2}$ was a strong antifeedant to $S$. littoralis $\left(\mathrm{EC}_{50}=0.64 \mu \mathrm{g} / \mathrm{cm}^{2}\right)$ while the maaliane 4 affected M. persicae $\left(\mathrm{EC}_{50}\right.$ $=0.97 \mu \mathrm{g} / \mathrm{cm}^{2}$ ). Antifeedant furanoeremophilanes have been described in Senecio species such as $S$. magellanicus (against M. persicae and S. littoralis) [2] and S. otites (against M. persicae and R. padi) [11,18]. 
Table 4. Antifeedant activity of S. fistulosus compounds 1, 2, 4 .

\begin{tabular}{|c|c|c|c|c|}
\hline Compound & $\begin{array}{c}\text { S. littoralis } \\
\% \mathrm{FI}\left(50 \mu \mathrm{g} / \mathrm{cm}^{2}\right)^{\mathrm{a}}\end{array}$ & $\mathrm{EC}_{50}\left(\mu \mathrm{g} / \mathrm{cm}^{2}\right)^{\mathrm{b}}$ & $\begin{array}{c}\text { M. persicae } \\
\% \mathrm{SI}^{\mathrm{b}}\left(50 \mu \mathrm{g} / \mathrm{cm}^{2}\right)^{\mathrm{a}}\end{array}$ & $\mathrm{EC}_{50}\left(\mu \mathrm{g} / \mathrm{cm}^{2}\right)^{\mathrm{b}}$ \\
\hline 1 & $65 \pm 6^{*}$ & & $52 \pm 7$ & \\
\hline 2 & $83 \pm 6^{*}$ & $0.64(0.36-1.16)$ & $52 \pm 7$ & \\
\hline 4 & $64 \pm 7^{*}$ & & $90 \pm 3^{*}$ & $0.97(0.71-1.32)$ \\
\hline
\end{tabular}

a $\% \mathrm{FI} / \% \mathrm{SI}=[1-(\mathrm{T} / \mathrm{C})] \times 100$, where $\mathrm{T}$ and $\mathrm{C}$ are the consumption/settling of treated and control leaf disks, respectively. ${ }^{\mathrm{b}}$ Effective antifeedant dose $\left(\mathrm{EC}_{50}\right)$ and $95 \%$ confidence (lower, upper). ${ }^{*} p<0.05$, Wilcoxon paired test.

Furanoeremophilanes are less abundant in Senecio than eremophilanolides. Therefore, the studies on their structure-activity relationships (SAR) are limited. Table 5 shows a compilation of the available information on the SAR of these structures, including the results presented in this work. The active compounds against the aphid $M$. persicae are characterized by the absence of substituents in C-1, C-3 and $\mathrm{C}-10$, regardless of the substituent in $\mathrm{C}-6(\mathbf{8 - 1 0}, \mathbf{1 1}, \mathbf{1 2})$. The presence of $\beta-\mathrm{OH} / \mathrm{C}-1$ and the $\alpha-\mathrm{OAng} / \mathrm{C}-3$ group (compound 2 ) resulted in an important antifeedant activity against $S$. littoralis. In addition, the C-6 substitution pattern together with the C-1/C-10 unsaturation determined post-ingestion effects on S. littoralis [11].

Table 5. Antifeedant structure-activity relationships of Senecio furanoeremophilanes against $S$. littoralis and M. persicae.

\begin{tabular}{|c|c|c|c|c|c|c|}
\hline \multirow{2}{*}{ Compound } & \multicolumn{4}{|c|}{ Substituent } & \multirow{2}{*}{$\frac{\text { S. littoralis }}{\%^{\mathrm{c} \mathrm{I}^{\mathrm{c}}}\left(\mathrm{EC}_{50}\right)^{\mathrm{d}}}$} & \multirow{2}{*}{$\begin{array}{l}\text { M. persicae } \\
\%^{\mathrm{SSI}}{ }^{\mathrm{c}}\left(\mathrm{EC}_{50}\right)^{\mathrm{c}}\end{array}$} \\
\hline & $C-1$ & $\mathrm{C}-3$ & C-6 & C-10 & & \\
\hline 1 & $\alpha$-OAng & $\mathrm{H}_{2}$ & $\beta-\mathrm{OAc}$ & $\beta-\mathrm{OH}$ & 65.0 & 52.0 \\
\hline 2 & $\alpha-\mathrm{OH}$ & $\alpha$-OAng & $\mathrm{H}_{2}$ & $\alpha-\mathrm{H}$ & $83.0(0.64)$ & 52.0 \\
\hline $8^{a}$ & $\Delta^{1}$ & $\mathrm{H}_{2}$ & $\beta$-OAng & $\Delta^{10}$ & 32.0 & 67.0 \\
\hline $9^{a}$ & $\Delta^{1}$ & $\mathrm{H}_{2}$ & $\beta-\mathrm{OH}$ & $\Delta^{10}$ & 62.0 & 71.0 \\
\hline $10^{a}$ & $\Delta^{1}$ & $\mathrm{H}_{2}$ & $\beta-\mathrm{OCOCH}_{2} \mathrm{CH}_{3}$ & $\Delta^{10}$ & 45.0 & 75.0 \\
\hline $11^{b}$ & $\mathrm{H}_{2}$ & $\mathrm{H}_{2}$ & $\beta-\mathrm{OAc}$ & $\alpha-H$ & 51.0 & $74.0(21.9)$ \\
\hline $12^{b}$ & $\mathrm{H}_{2}$ & $\mathrm{H}_{2}$ & $\beta$-OTigl & $\alpha-\mathrm{H}$ & 65.0 & $74.0(12.2)$ \\
\hline
\end{tabular}

${ }^{a}$ Compounds 8-10 from Domínguez et al. [11]. ${ }^{\mathrm{b}}$ Compounds 11, 12 from Reina et al. [2]. ${ }^{\mathrm{c}} \% \mathrm{FI} / \%$ SI values at $50 \mu \mathrm{g} / \mathrm{cm}^{2} .{ }^{\mathrm{d}}$ Effective antifeedant dose $\left(\mu \mathrm{g} / \mathrm{cm}^{2}\right)$.

Maalianes have been isolated from a range of organisms, such as liverworts, marine sponges, soft corals and bacteria, however, they are not abundant in nature. A small amount of biological activity has been reported and includes fish toxicity, in vitro antimalarial activity, cytotoxicity and antimicrobial [19]. This is the first report on the insect antifeedant effects of a maaliane sesquiterpene.

PAs 5 and 6, with necines of the rosmarinecine and petasinecine type (1,2-saturated base), were isolated from the alkaloidal extract of $S$. fistulosus. The role of PAs as plant defenses against phytophagous insects has been widely documented [20], however, this alkaloidal extract showed moderate-low antifeedant activity $(62 \pm 6 \% \mathrm{FR}$ against $S$. littoralis and $69 \pm 6 \% \mathrm{SI}$ against $R$. padi).

PAs with unsaturated retronecines are potentially more toxic than rosmarinecine and petasinecine type (1,2-saturated base) PAs [21]. For example, rosmarinine with a petasinecine, did not form hepatotoxic reactive pyrrole intermediates $[22,23]$ and cytotoxic assays have demonstrated a higher toxicity of retronecine and otonecine PAs compared with platynecine PAs [24]. Therefore, PAs 5 and $\mathbf{6}$ have a low risk of associated toxicity.

\section{Materials and Methods}

\subsection{General}

For column chromatography (CC), Si-gel (107734, 107741, and 107749, Merck) and Sephadex LH-20 (Sigma-Aldrich) were used. For TLC chromatography, Si-gel (105554 and 105715; Merck) 
plates were used and visualized with óleum solution (sesquiterpenes) and Dragendorff's reagent (alkaloids). The prep. HPLC chromatography was carried out on a Beckman 125P system equipped with an Ultrasphere semiprep column $(10 \times 250 \mathrm{~mm})$ and a UV/visible diode array detector 168 . Optical rotations were determined at $20^{\circ} \mathrm{C}$ on a Perkin-Elmer 343 Plus polarimeter. IR Spectra were recorded in $\mathrm{CHCl}_{3}$ on a Perkin Elmer 1600 spectrophotometer. NMR spectra were recorded on a pulsed-field gradient Bruker Advance II-500 MHz spectrometer (solvent as internal standard $\mathrm{CDCl}_{3}$, at $\delta_{\mathrm{H}} 7.26$ and $\delta_{\mathrm{C}} 77.0$ ) and the Bruker software was used for DEPT, ${ }^{1} \mathrm{H},{ }^{1} \mathrm{H}$-COSY (Homonuclear correlation spectroscopy), NOESY (Nuclear Overhauser Effect Spectroscopy), HSQC (Heteronuclear single quantum coherence spectroscopy) and HMBC (Heteronuclear Multiple Bond Correlation). EI and HR-EI-MS spectra were recorded in $\mathrm{m} / \mathrm{z}$ on a Micromass Autospec spectrometer.

\subsection{Extraction and Isolation}

Aerial parts of S. fistulosus (Asteraceae), identified by Orlando Dollenz, were collected in Sierra Baguales (March 2009, Punta Arenas, Magallanes, Chile,) during the flowering period. A voucher specimen (\# 7569) has been deposited in the Herbarium of the Patagonian Institute, Magallanes University (UMAG), Punta Arenas, Chile.

Grounded dried aerial plant parts $(2.50 \mathrm{~kg})$ were extracted with $\mathrm{MeOH}(20 \mathrm{~L})$ at room temperature for a week to give a crude $\mathrm{MeOH}$ extract $(190.5 \mathrm{~g}$, 7.62\% yield of plant dry weight). The $\mathrm{MeOH}$ extract (157.6 g) was treated with a $\mathrm{f}_{2} \mathrm{SO}_{4} 0.5 \mathrm{M}$ and $\mathrm{CH}_{2} \mathrm{Cl}_{2}$ (1:1) solution. Zinc dust was used to reduce the aqueous phase under continuous stirring (4-6 hours) and then filtered, basified ( $30 \%$ $\left.\mathrm{NH}_{4} \mathrm{OH}, \mathrm{pH}=8-9\right)$ and extracted with $\mathrm{CH}_{2} \mathrm{Cl}_{2}$ (236.0 mg of alkaloids, $9.4 \times 10^{-3} \%$ ). The organic phase, dried over anhydrous $\mathrm{Na}_{2} \mathrm{SO}_{4}$ (non-alkaloidal fraction, $9.0 \mathrm{~g}, 0.36 \%$ ), was chromatographed on a $\mathrm{SiO}_{2}$ vacuum-liquid chromatography column (VLC) and eluted with a hexane/EtOAc/MeOH gradient to give seven fractions. Fr-0 (hexane 100\%, $360.7 \mathrm{mg}$ ), Fr-1, (hexane/EtOAc 95:5\%, $2.2 \mathrm{~g}$ ), Fr-2 (hexane/EtOAc 90:10\%, 1.7 g), Fr-3 (hexane/EtOAc 75:25\%, 1.1 g), Fr-4 (hexane/EtOAc 50:50\%, 966.6 mg), Fr-5 (EtOAc 100\%, $478.2 \mathrm{mg}$ ), Fr-6 (MeOH 100\%, $2.6 \mathrm{~g})$. Fr-1 (2.2 g, $8.8 \times 10^{-2} \%$ ) was further chromatographed on a CC Sephadex LH-20 column, CC silica gel and semi-preparative normal-phase HPLC eluted with an isocratic mixture of hexane/EtOAc at $3 \mathrm{ml} / \mathrm{min}$ flow rate to give compound 4 (16.1 mg, $\left.6.4 \times 10^{-4 \%}\right)$. Fr-2 (1.7 g) was chromatographed on CC Sephadex LH-20, CC silica gel, circular chromatography and semi-preparative normal phase HPLC eluted with an isocratic mixture of hexane/EtOAc at a flow rate of $3 \mathrm{ml} / \mathrm{min}$ to give compounds $1\left(41.0 \mathrm{mg}, 1.6 \times 10^{-3 \%}\right), 2(29.9 \mathrm{mg}$, $\left.1.2 \times 10^{-3} \%\right)$ and $3\left(3.5 \mathrm{mg}, 1.4 \times 10^{-4} \%\right)$.

The alkaloidal fraction was submitted to neutral alumina CC, eluted with an EtOAc/MeOH gradient and PTLC $(20 \times 20 \mathrm{~cm}, 0.25 \mathrm{~mm})$ to give compounds $5\left(1.3 \mathrm{mg} ; 5.2 \times 10^{-5} \%\right)$ and $6(0.9 \mathrm{mg}$; $\left.3.6 \times 10^{-5} \%\right)$.

\subsection{1. $\alpha$-Angeloyloxy-6 $\beta$-acetoxy-10 $\beta$-hydroxy-9-oxo-furanoeremophilane (1)}

Colorless crystal, $\mathrm{mp} 127-130{ }^{\circ} \mathrm{C}$ (hexane/EtOAc); $[\alpha]_{D}^{20}-28.2\left(c, 0.82, \mathrm{CHCl}_{3}\right)$. IR $\left(\mathrm{CHCl}_{3}\right) v_{\text {máx }}$ : 3452, 1748, 1720, 1679, $1232 \mathrm{~cm}^{-1}$. EI-MS: $404\left(1, \mathrm{M}^{+}\right), 345$ (3), 260 (20), 262 (12), 178 (55), 136 (4), 91 (4), 83 (100), 57 (8), 55 (39). HR-EI-MS: $404.1838\left(\mathrm{M}^{+}, \mathrm{C}_{22} \mathrm{H}_{28} \mathrm{O}_{7}\right.$; calculated for 404.1835). For ${ }^{1} \mathrm{H}$ and ${ }^{13} \mathrm{C}$ NMR data see Table 1.

\subsection{2. $\alpha$-hydroxy-3 $\alpha$-angeloyloxy-10 $\alpha \mathrm{H}$-9-oxo-furanoeremophilane (2)}

White amorphous solid; $[\alpha]_{D}^{20}-37.5\left(c, 0.59, \mathrm{CHCl}_{3}\right)$. IR $\left(\mathrm{CHCl}_{3}\right) \nu_{\text {máx }}: 3446,1733,1716,1699$, $1456 \mathrm{~cm}^{-1}$. EI-MS: 346 (3, M+), 246 (9), 228 (10), 213 (18), 191 (8), 163 (100), 135 (9), 105 (5), 91 (13), 83 (19), 77 (7), 55 (24). HR-EI-MS: $346.1785\left(\mathrm{M}^{+}, \mathrm{C}_{20} \mathrm{H}_{26} \mathrm{O}_{5}\right.$; calculated for 346.1780$)$. For ${ }^{1} \mathrm{H}$ and ${ }^{13} \mathrm{C} N M R$ data see Table 1 [12]. 


\subsection{3. $\beta, 10 \beta$-epoxy-6 $\beta$-acetoxy-8 $\alpha$-hydroxy-eremophil-7(11)-en-8 $\beta, 12$-olide (3)}

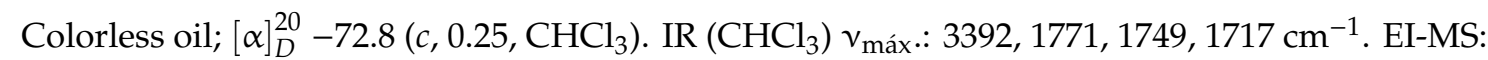
$322\left(0.4, \mathrm{M}^{+}\right), 298$ (2), 280 (3), 262 (100), 244 (7), 216 (6), 142 (100), 124 (50), 95 (63). HR-EI-MS: 322.1425 $\left(\mathrm{M}^{+}, \mathrm{C}_{17} \mathrm{H}_{22} \mathrm{O}_{6}\right.$; calculated for 322.1416). For ${ }^{1} \mathrm{H}$ and ${ }^{13} \mathrm{C}$ NMR data see Table 2.

\subsection{4. (+)-1(14)-en-maaliol (4)}

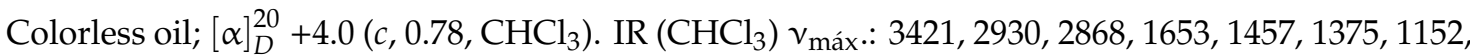
913, 889, $668 \mathrm{~cm}^{-1}$. EI-MS: $220\left(5, \mathrm{M}^{+}\right), 205$ (55), 187 (19), 177 (12), 162 (24), 159 (34), 147 (36), 133 (29), 121 (38), 119 (60), 105 (75), 93 (78), 91 (100), 79 (93), 69 (85). HR-EI-MS: $220.1831\left(\mathrm{M}^{+}, \mathrm{C}_{15} \mathrm{H}_{24} \mathrm{O}\right.$; calculated for 220.1827). For ${ }^{1} \mathrm{H}$ and ${ }^{13} \mathrm{C}$ NMR spectral data see Table 3.

\subsubsection{9-O-angelylpetasinecine (hectorine) (5)}

Colorless oil; $[\alpha]_{D}^{20}-62.86\left(c, 0.07, \mathrm{CHCl}_{3}\right)$. EI-MS: $239\left(9, \mathrm{M}^{+}\right), 222(9), 190(3), 188(11), 140(61)$, 122 (9), 111 (9), 83 (100), 70 (11), 68 (6), 55 (27). HR-EI-MS: $239.1512\left(\mathrm{M}^{+}, \mathrm{C}_{13} \mathrm{H}_{21} \mathrm{NO}_{3}\right.$; calculated for 239.1521). ${ }^{1} \mathrm{H}$ NMR $\left(\mathrm{CDCl}_{3}, 500 \mathrm{MHz}\right): \delta_{\mathrm{H}} 2.51\left(1 \mathrm{H}, \mathrm{m}, \mathrm{H}_{\alpha}-\mathrm{C}(1)\right), 4.23\left(1 \mathrm{H}, \mathrm{t}, J=3.9 \mathrm{~Hz}, \mathrm{H}_{\alpha}-\mathrm{C}(2)\right), 3.42$ $\left(1 \mathrm{H}, \mathrm{dd}, J=4.0,13.0 \mathrm{~Hz}, \mathrm{H}_{\alpha}-\mathrm{C}(3)\right), 3.03\left(1 \mathrm{H}, \mathrm{d}, J=13.0, \mathrm{~Hz}, \mathrm{H}_{\beta}-\mathrm{C}(3)\right), 3.50\left(1 \mathrm{H}, \mathrm{t}, J=8.5 \mathrm{~Hz}, \mathrm{H}_{\alpha}-\mathrm{C}(5)\right)$, $2.98\left(1 \mathrm{H}, \mathrm{m}, \mathrm{H}_{\beta}-\mathrm{C}(5)\right), 1.84\left(1 \mathrm{H}, \mathrm{m}, \mathrm{H}_{\alpha}-(6)\right), 2.06\left(1 \mathrm{H}, \mathrm{m}, \mathrm{H}_{\beta}-\mathrm{C}(6)\right), 1.80\left(1 \mathrm{H}, \mathrm{m}, \mathrm{H}_{\alpha}-\mathrm{C}(7)\right), 1.99(1 \mathrm{H}$, $\left.\mathrm{m}, \mathrm{H}_{\beta}-\mathrm{C}(7)\right), 3.90\left(1 \mathrm{H}, \mathrm{m}, \mathrm{H}_{\alpha}-\mathrm{C}(8)\right), 4.73\left(1 \mathrm{H}, \mathrm{dd}, J=10.0,11.5 \mathrm{~Hz}, \mathrm{H}_{\mathrm{d}}-\mathrm{C}(9)\right), 4.15(1 \mathrm{H}, \mathrm{dd}, J=4.9$, $\left.11.5 \mathrm{~Hz}, \mathrm{H}_{\mathrm{u}}-\mathrm{C}(9)\right), 6.15\left(1 \mathrm{H}, \mathrm{cc}, J=1.5,7.2 \mathrm{~Hz}, \mathrm{H}-\left(3^{\prime}\right)\right), 1.99\left(3 \mathrm{H}, \mathrm{d}, J=7.0 \mathrm{~Hz}, \mathrm{H}-\mathrm{C}\left(4^{\prime}\right)\right), 1.90$ (3H, quint., $\left.J=1.6 \mathrm{~Hz}, \mathrm{H}-\mathrm{C}\left(5^{\prime}\right)\right) .{ }^{13} \mathrm{C}-\mathrm{NMR}: \delta(\mathrm{C}) 46.3(\mathrm{~d}, \mathrm{C}-1), 73.2(\mathrm{~d}, \mathrm{C}-2), 61.6(\mathrm{t}, \mathrm{C}-3), 56.9(\mathrm{t}, \mathrm{C}-5), 27.2(\mathrm{t}, \mathrm{C}-6)$, $27.9(\mathrm{t}, \mathrm{C}-7), 66.7(\mathrm{~d}, \mathrm{C}-8), 60.3(\mathrm{t}, \mathrm{C}-9), 169.2\left(\mathrm{~s}, \mathrm{C}-1^{\prime}\right), 127.4\left(\mathrm{~s}, \mathrm{C}-2^{\prime}\right), 139.8\left(\mathrm{~d}, \mathrm{C}-3^{\prime}\right), 16.1\left(\mathrm{q}, \mathrm{C}-4^{\prime}\right), 20.7(\mathrm{q}$, C-5') [13].

\subsubsection{Rosmarinine (6)}

As a white resin; $[\alpha]_{D}^{20}-51.1\left(c, 0.09, \mathrm{CHCl}_{3}\right)$. EI-MS: $353\left(5, \mathrm{M}^{+}\right), 282(2), 227(4), 180(6), 156(43)$, 154 (87), 138 (100), 122 (32), 98 (27), 82 (86), 81 (21), 55 (41). HR-EI-MS: $353.1835\left(\mathrm{M}^{+}, \mathrm{C}_{18} \mathrm{H}_{27} \mathrm{NO}_{6}\right.$; calculated for 353.1838). ${ }^{1} \mathrm{H} \mathrm{NMR}\left(\mathrm{CDCl}_{3}, 500 \mathrm{MHz}\right): \delta(\mathrm{H}) 2.54\left(1 \mathrm{H}, \mathrm{m}, \mathrm{H}_{\alpha}-\mathrm{C}(1)\right), 4.26\left(1 \mathrm{H}, \mathrm{m}, \mathrm{H}_{\beta}-\mathrm{C}(2)\right)$, $3.15\left(1 \mathrm{H}, \mathrm{dd}, J=7.3,11.2 \mathrm{~Hz}, \mathrm{H}_{\alpha}-\mathrm{C}(3)\right), 2.94\left(1 \mathrm{H}, \mathrm{dd}, J=7.9,11.3 \mathrm{~Hz}, \mathrm{H}_{\beta}-\mathrm{C}(3)\right), 3.33(1 \mathrm{H}, \mathrm{t}, J=8.9 \mathrm{~Hz}$, $\left.\mathrm{H}_{\alpha}-\mathrm{C}(5)\right), 2.60\left(1 \mathrm{H}, \mathrm{m}, \mathrm{H}_{\beta}-\mathrm{C}(5)\right), 2.08\left(1 \mathrm{H}, \mathrm{m}, \mathrm{H}_{\alpha}-\mathrm{C}(6)\right), 2.27\left(1 \mathrm{H}, \mathrm{m}, \mathrm{H}_{\beta}-\mathrm{C}(6)\right), 5.08(1 \mathrm{H}, \mathrm{t}, J=2.9 \mathrm{~Hz}$, $\left.\mathrm{H}_{\alpha}-\mathrm{C}(7)\right), 3.71\left(1 \mathrm{H}, \mathrm{dd}, J=3.4,7.8 \mathrm{~Hz}, \mathrm{H}_{\alpha}-\mathrm{C}(8)\right), 4.89\left(1 \mathrm{H}, \mathrm{dd}, J=5.4,12.6 \mathrm{~Hz}, \mathrm{H}_{\mathrm{d}}-\mathrm{C}(9)\right), 4.11(1 \mathrm{H}$, $\left.\mathrm{dd}, J=1.1,12.6 \mathrm{~Hz}, \mathrm{H}_{\mathrm{u}}-\mathrm{C}(9)\right), 1.80\left(1 \mathrm{H}, \mathrm{m}, \mathrm{H}_{\beta}-\mathrm{C}(13)\right), 2.27\left(1 \mathrm{H}, \mathrm{m}, \mathrm{H}_{\mathrm{a}}-\mathrm{C}(14)\right), 1.96\left(1 \mathrm{H}, \mathrm{m}, \mathrm{H}_{\mathrm{b}}-\mathrm{C}(14)\right)$, $1.34\left(3 \mathrm{H}, \mathrm{s}, \mathrm{H}_{\alpha}-\mathrm{C}(18)\right), 0.97\left(3 \mathrm{H}, \mathrm{d}, J=6.7 \mathrm{~Hz}, \mathrm{H}_{\alpha}-\mathrm{C}(19)\right), 5.80(1 \mathrm{H}, \mathrm{c}, J=7.1 \mathrm{~Hz}, \mathrm{H}-(20)), 1.85(3 \mathrm{H}, \mathrm{dd}$, $J=1.5,7.2 \mathrm{~Hz}, \mathrm{H}-\mathrm{C}(21)) .{ }^{13} \mathrm{C}-\mathrm{NMR}: \delta(\mathrm{C}) 49.1(\mathrm{~d}, \mathrm{C}-1), 69.3(\mathrm{~d}, \mathrm{C}-2), 60.9(\mathrm{t}, \mathrm{C}-3), 53.5(\mathrm{t}, \mathrm{C}-5), 34.6(\mathrm{t}$, C-6), 75.2 (d, C-7), 69.6 (d, C-8), 62.3 (t, C-9), 180.7 (s, C-11), 77.6 (s, C-12), 38.0 (d, C-13), 39.7 (t, C-14), 132.7 (s, C-15), 167.6 (s, C-16), 25.8 (q, C-18), 11.9 (q, C-19), 134.9 (d, C-20), 15.3 (q, C-21) [14].

\subsubsection{Crystal Structure Analysis}

Intensity data, for both compounds, were collected at $293 \mathrm{~K}$ on an Oxford Diffraction Supernova dual Atlas CCD diffractometer, using Cu K $\alpha(\lambda=1.5418 \AA)$ radiation. Data collection, cell refinement and data reduction were performed with the CrysAlisPRO [25] set of programs. The structure was solved by direct methods using SIR97 [26]. Refinements were performed with SHELXL-97 [27] using full-matrix least squares, with anisotropic displacement parameters for all the non-hydrogen atoms. The H-atoms were placed at calculated positions with C-H distances 0.95-1.00 $\AA$ and refined using a riding model. Calculations were mainly performed with WinGX [28] and molecular graphics were computed with PLATON [29].

X-ray crystal data: $\mathrm{C}_{22} \mathrm{H}_{28} \mathrm{O}_{7}, \mathrm{Mw}=404.44$, orthorhombic, space group, $\mathrm{P} 2{ }_{1} 2{ }_{1} 2{ }_{1}, \mathrm{Z}=8$, $\mathrm{a}=8.7493(2), \mathrm{b}=13.4234, \mathrm{c}=37.0309(11) \AA ; \mathrm{V}=4349.1(2) \AA^{3}, \mu(\mathrm{Cu} \mathrm{K} \alpha)=0.76 \mathrm{~mm}^{-1}, \rho_{\text {calc }}=1.23 \mathrm{~g} . \mathrm{cm}^{-3}$; $S=1.06$, final $R$ indices: $R_{1}=0.0678$ and $R w=0.1860$ for 7134 observed from 8339 independent and 15715 measured reflections $\left(\theta_{\max }=70.99, \mathrm{I}>2 \sigma(\mathrm{I})\right.$ criterion and 536 parameters); maximum and 
minimum residues are and 0.30 and -0.24 e. $\AA^{-3}$ respectively. There are two independent molecules in the asymmetric unit with minor conformational differences between them. The absolute structure is based on the refinement of the Flack [30] (Flack 1983), $x=0.0$ (3), parameter against 3610 CuK $\alpha$ Bijvoet pairs. The Hooft [31] analysis yielded $y=0.06(8)$ and P2 (true) $=1.000$.

Crystallographic data (excluding structure factor tables) has been deposited with de Cambridge Crystallographic Data Center as supplementary publications no. CCDC1455588. Copies of the data can be obtained free of charge on application to The Director, CCDC, 12 Union Road, Cambridge CB1EZ, UK ((Fax: Int. + (1223) 336 033); e-mail: deposit@ccdc.cam.ac.uk)).

\subsection{Insect Bioassays}

S. littoralis, M. persicae and R. padi colonies were reared on an artificial diet [32], bell pepper (Capsicum annuum) and barley (Hordeum vulgare) plants, respectively. The plants are grown from seeds in pots with commercial substrate. The plants for rearing aphids are infected regularly (bell pepper plants with 4 leaves, barley plants of $10 \mathrm{~cm}$ length). The insect colonies and host plants were maintained at $22 \pm 1{ }^{\circ} \mathrm{C},>70 \%$ relative humidity with a photoperiod of $16: 8 \mathrm{~h}(\mathrm{~L}: \mathrm{D})$ in a growth chamber.

Antifeedant bioassays: The upper surface of $C$. anuum and $H$. vulgare leaf disks or fragments $\left(1.0 \mathrm{~cm}^{2}\right)$ were treated with $10 \mu \mathrm{l}$ of the test substance. The crude extracts and products were tested at an initial dose of $100 \mathrm{or} 50 \mu \mathrm{g} / \mathrm{cm}^{2}$ respectively. Five Petri dishes $(9 \mathrm{~cm}$ diam.) or twenty ventilated plastic boxes $(2 \times 2 \mathrm{~cm})$ with two newly molted S. littoralis L6 larvae $(\leq 24 \mathrm{~h})$ or ten apterous aphid adults (24-48 h old) each were allowed to feed at room temperature for S. littoralis $(<2 \mathrm{~h})$ or in a growth chamber for the aphids ( $24 \mathrm{~h}$, environmental conditions as above). Each experiment was repeated 2-3 times ( $\mathrm{SE}<10 \%$ ) and terminated when the consumption of the control disks reached $65-75 \%$ for $S$. littoralis or after $24 \mathrm{~h}$ for aphids. The leaf disk area consumed was measured on their digitalized images (Image J, http://imagej.nih.gov/ij). Settling was measured by counting the number of aphids settled on each leaf fragment. Feeding or settling inhibition (\%FI or \%SI) was calculated as $\% \mathrm{FI} / \% \mathrm{SI}=[1-(\mathrm{T} / \mathrm{C}) \times 100]$, where $\mathrm{T}$ and $\mathrm{C}$ are the consumption/settling of treated and control leaf disks, respectively. The antifeedant effects (\% FI/SI) were analyzed for significance by the nonparametric Wilcoxon signed-rank test. Extracts and compounds with an FI/SI $\leq 75 \%$ were further tested in a dose-response experiment (3-4 serial dilutions) to calculate their relative potency $\left(\mathrm{EC}_{50}\right.$, the effective dose to give a 50\% feeding/settling reduction) from a linear regression analysis (\% FI/SI on Log-dose) [33].

\section{Conclusions}

Senecio fistulosus is characterized by their content in sesquiterpenes (furanoeremophilanes, eremophilanolides and maaliane type) and pyrrolizidine alkaloids. The antifeedant properties of ethanolic, non-alkaloidal, alkaloidal extracts and compounds have been studied. Most of the insect antifeedant effects were found in the ethanolic and non-alkaloidal extracts, containing mainly sesquiterpenes with low amounts of PAs. The isolated furanoeremophilanes sesquiterpenes type had structure-dependent antifeedant effects. In addition to their antifeedant action, these sesquiterpenes could play a role in insect-plant interactions.

Author Contributions: Conceptualization, A.G.-C., M.R. and V.F.; funding acquisition, A.G.-C.; investigation, A.G.-C., L.R.-V., M.L. and M.R.; methodology, A.G.-C., L.R.-V. and M.R.; resources, V.F.; writing-original draft, A.G.-C., M.L. and M.R.; writing-review \& editing, A.G.-C. and L.R.-V.

Funding: This work has been supported by grants CTQ2015-64049-C3-1-R, (MINECO/FEDER), UMAG 027103-026703 (Dirección de Investigación, Chile) and a JAEPRE-DOC-CSIC predoctoral fellowship to L.R.V.

Conflicts of Interest: The authors declare no conflicts of interest. 


\section{References}

1. Portero, A.G.; González-Coloma, A.; Reina, M.; Díaz, C.E. Plant-defensive sesquiterpenoids from Senecio species with biopesticide potential. Phytochem. Rev. 2012, 11, 391-403. [CrossRef]

2. Reina, M.; Santana, O.; Domínguez, D.M.; Villarroel, L.; Fajardo, V.; López-Rodríguez, M.; González-Coloma, A. Defensive sesquiterpenes from Senecio candidans and S. magellanicus, and their structure-activity relationships. Chem. Biodivers. 2012, 9, 625-643. [CrossRef] [PubMed]

3. Ruiz-Vásquez, L.; Reina, M.; López-Rodríguez, M.; Giménez, C.; Cabrera, R.; Cuadra, P.; Fajardo, V.; González-Coloma, A. Sesquiterpenes, flavonoids, shikimic acid derivatives and pyrrolizidine alkaloids from Senecio kingii Hook. Phytochemistry 2015, 117, 245-253. [CrossRef] [PubMed]

4. Ruiz-Vásquez, L.; Olmeda, A.S.; Zuñiga, G.; Villarroel, L.; Echeverri, L.F.; González-Coloma, A.; Reina, M. Insect Antifeedant and Ixodicidal Compounds from Senecio adenotrichius. Chem. Biodivers. 2017, 14, e1600155. [CrossRef] [PubMed]

5. Ruiz-Vásquez, L.; Ruiz Mesia, L.; Reina-Artiles, M.; López-Rodríguez, M.; González-Platas, J.; Giménez, C.; Cabrera, R.; González-Coloma, A. Benzofurans, benzoic acid derivatives, diterpenes and pyrrolizidine alkaloids from Peruvian Senecio. Phytochem. Lett. 2018, 28, 47-54. [CrossRef]

6. Agullo-Ortuño, M.T.; Diaz, C.E.; Gonzalez-Coloma, A.; Reina, M. Structure-Dependent Cytotoxic Effects of Eremophilanolide Sesquiterpenes. Nat. Prod. Commun. 2017, 12, 663-665. [CrossRef] [PubMed]

7. Henríquez, J.M.; Pisano, E.; Marticorena, C. Catálogo de la Flora Vascular de Magallanes (XII Región); Anales Instituto de la Patagonia, Sección Ciencias Naturales, Universidad de Magallanes: Punta Arenas, Chile, 1995; pp. 5-30.

8. Arias Cassará, M.L.; Borkosky, S.A.; González Sierra, M.; Bardón, A.; Ybarra, M.I. Two new furanoeremophilanes from Senecio santelisis. Chem. Biodivers. 2010, 7, 1745-1753. [CrossRef] [PubMed]

9. Bolzan, A.A.; Silva, C.M.; Francescato, L.N.; Murari, A.L.; Silva, G.N.; Heldwein, C.G.; Heinzmann, B. Espécies de Senecio na Medicina Popular da América Latina e Toxicidade Relacionada a sua Utilização. Lat. Am. J. Pharm. 2007, 26, 619-625.

10. Villarroel, L.; Torres, R.J. A new furanoeremophilane from Senecio fistulosus. J. Nat. Prod. 1985, 48, 841-842. [CrossRef]

11. Domínguez, D.M.; Reina, M.; Villarroel, L.; Fajardo, V.; González-Coloma, A. Bioactive Furanoeremophilanes from Senecio otites Kunze ex DC.Z. Naturforsch 2008, 63c, 837-842. [CrossRef]

12. Bohlmann, F.; Zdero, C.; King, R.M.; Robinson, H. Furanoeremophilanes from Senecio smithii. Phytochemistry 1981, 20, 2389-2391. [CrossRef]

13. Bai, Y.; Benn, M.; Duke, N.; Gul, W.; Huangand, Y.Y.; Rüeger, H. The alkaloids of Brachyglottis hectori. Arkivoc 2006, 3, 34-42.

14. Were, O.; Benn, M.; Munavu, R.M. The pyrrolizidine alkaloids of Senecio syringifolius and S. hadiensis from Kenya. Phytochemistry 1993, 32, 1595-1602. [CrossRef]

15. Naya, K.; Nogi, N.; Makiyama, Y.; Takashima, H.; Imagawa, T. The Photosensitized Oxygenation of Furanoeremophilanes. II. The Preparation and Stereochemistry of the Isomeric Hydroperoxides and the Corresponding Lactones from Furanofukinin and Furanoeremophilane. Bull. Chem. Soc. Jpn. 1977, 50, 3002-3006. [CrossRef]

16. Harrie, J.M.; Joannes, B.P.A.; Wijnberg, C.R.; Groom, A. Rearrangement reactions of aromadendrane derivatives. The synthesis of (+)-maaliol, starting from natural (+)-aromadendrene-IV. Tetrahedron 1994, 50, 4733-4744.

17. De Pascual, T.; Urones, J.G.; Fernández, A. An aristolochic acid derivative from Aristolochia longa. Phytochemistry 1983, 22, 2753-2754. [CrossRef]

18. Gutierrez, C.; Fereres, A.; Reina, M.; Cabrera, R.; González-Coloma, A. Behavioral and sublethal effects of structurally related lower terpenes on Myzus persicae. J. Chem. Ecol. 1997, 23, 1641-1650. [CrossRef]

19. Duran-Peña, M.J.; Ares, J.M.B.; Hanson, J.R.; Collado, I.G.; Hernandez-Galan, R. Biological activity of natural sesquiterpenoids containg a gem-dimethylcyclopropane unit. Nat. Prod. Rep. 2015, 32, 1236-1248. [CrossRef]

20. Hartmann, T. Chemical ecology of pyrrolizidine alkaloids. Planta 1999, 207, 483-495. [CrossRef]

21. Castells, E.; Mulder, P.P.J.; Pérez-Trujillo, M. Diversity of pyrrolizidine alkaloids in native and invasive Senecio pterophorus (Asteraceae): Implications for toxicity. Phytochemistry 2014, 108, 137-146. [CrossRef] 
22. Culvenor, C.C.J.; Edgar, J.A.; Smith, L.W.; Jago, M.V.; Peterson, J.E. Active metabolites in the chronic hepatotoxicity of pyrrolizidine alkaloids, including otonecine esters. Nat. New Biol. 1971, 229, 255-256. [CrossRef]

23. Styles, J.; Asbey, J.; Mattocks, A.R. Evaluation in vitro of several pyrrolizidine alkaloid carcinogens: Observations on the essential pyrrolic nucleus. Carcinogenesis 1980, 1, 161-164. [CrossRef] [PubMed]

24. Li, Y.H.; Kan, W.L.T.; Li, N.; Lin, G. Assessment of pyrrolizidine alkaloid induced toxicity in an in vitro screening model. J. Ethnopharmacol. 2013, 150, 560-567. [CrossRef] [PubMed]

25. CrysAlis RED Version 1.171.32.5; Oxford Diffraction Ltd.: Abingdon, UK, 2007.

26. Altomare, A.; Cascarano, G.; Giacovazzo, C.; Guagliardi, A.; Moliterni, A.G.G.; Burla, M.C.; Polidor, G.; Camalli, M. Spagna R. SIR97; University of Bari: Bari, Italy, 1997.

27. Sheldrick, G.M. A short history of SHELX. Acta Cryst. 2008, A64, 112-122. [CrossRef] [PubMed]

28. Farrugia, L.J. WinGX suite for small-molecule single-crystal crystallography. J. Appl. Cryst. 1999, 32, 837-838. [CrossRef]

29. Spek, A.L. Single-crystal structure validation with the program PLATON. J. Appl. Cryst. 2003, 36, 7-13. [CrossRef]

30. Flack, H.D. On enantiomorph-polarity estimation. Acta Cryst. 1983, A39, 876-881. [CrossRef]

31. Hooft, R.W.W.; Straver, L.H.; Spek, A.L. Determination of absolute structure using Bayesian statistics on Bijvoet differences. J. Appl. Cryst. 2008, 41, 96-103. [CrossRef]

32. Poitout, S.; Bues, S. Elevage de plusieursespeces de Lepidopteres Noctuidae sur milleu artificiel simplifié. Ann. Zool. Ecol. Anim. 1970, 2, 79-91.

33. Burgueño-Tapia, E.; Castillo, L.; González-Coloma, A.; Joseph-Nathan, P. Antifeedant and phytotoxic activity of the sesquiterpene p-benzoquinone perezone and some of its derivatives. J. Chem. Ecol. 2008, 34, 766-771. [CrossRef]

(C) 2019 by the authors. Licensee MDPI, Basel, Switzerland. This article is an open access article distributed under the terms and conditions of the Creative Commons Attribution (CC BY) license (http://creativecommons.org/licenses/by/4.0/). 